\title{
The Role of Children's Media Use in Teacher-Child Relationship, Classroom Adjustment and Performance When Transit to Primary School
}

\author{
Yanfang Zhou \\ Graduate School of Education, Hiroshima University \\ 1-1-,1Kagamiyama,Higashi-Hiroshima City,Hiroshima,739-8524,Japan \\ E-mail: fantella729@yahoo.co.jp \\ Atsushi Nanakida \\ Graduate School of Education, Hiroshima University \\ 1-1-,1Kagamiyama,Higashi-Hiroshima City,Hiroshima,739-8524,Japan \\ E-mail: nanakida@hiroshima-u.ac.jp
}

\begin{abstract}
Early transition from preschool to primary school is an important predictor that gives a lot of insight into the later years of formal schooling.In this process,teacher-child relationship is a determining factor on social and academic success when children make an attempt to adjust to the school environment. The major purpose of the study was to examine the teacher-child relationship in children's media use with a focus on the teacher-child interaction,classroom adjustment and performance.Correlation and regression analyses were used to identify these variables.Participants were 250 children $(\mathrm{N}=250,121$ girls, 129 boys $)$ across the first year of primary school. 250 families as well as the teachers of children were surveyed on the children's media use and teacher-child relationship.Correlation analyses indicated that the quality of teacher-child relationship was linked to children' media use.Key findings suggest that the longer the media is used by a child, the less likely he/she is to interact with the teacher.What's more,the more the teacher assigns assignments through the mobile phone or tablet, the less child admires the teacher,which as well could reduce the class satisfaction via teacher-child interaction in sequence.Additionally, this study also indicates that media assignments by teachers is a new risk factor of negative relationship via teacher-child interaction.
\end{abstract}

Keywords: children's media use,transit to primary school,teacher-child relationship,classroom adjustment and performance

DOI: $10.7176 / \mathrm{JEP} / 11-6-01$

Publication date: February $29^{\text {th }} 2020$

\section{Introduce}

Starting school is a milestone for all children, and their early years transition predicts later school success (Gutman, Sameroff, \& Cole,2003; Jacynta Krakouer, Pru Mitchell\& Jenny Trevitt,2017;Entwisle\& Alexander, 1998;Pianta, Cox, Taylor,\& Early, 1999;Claessens, Engel, \& Curran, 2013;Morgan, Farkas, Hillemeier, \& Maczuga, 2016). When children first step foot into their formal schooling classrooms, they are often entering a new world that entails various relationships (such as peer relationship,teacher-child relationship) and expectations (Kupersmidt\&Coie,1990;Verschueren\&Koomen,2012;Acquah,Palonen, Laine\& Lehtinen, 2014). Gaining a greater understanding of the effect that the quality of these relationships has in children's lives can be a useful way to begin establishing high-quality relationships and provide positive outcomes for children (Rudasill \&RimmKaufman,2009;Ariana Pavelka,2016).

Increasing attention is being given to the children' transition from preschool to primary school under the ecological-contextual models (Bronfenbrenner,1977;Pianta\&Walsh,1996;Pianta, R. C., \& Stuhlman, M.W.2004;Pianta,R.C.,Steinberg,M.,\&Rollins,K.1995;Bronfenbrenner\&Morris,2007). According to the bioecological model,children gain development within interrelated systems that exist at levels proximal and distal to them,which occurs in the way of continuous interactions between children and contexts (Bronfenbrenner, 1977;Pianta \& Walsh, 1996), the various factors are in a network of mutual influence, the influence of a factor in one system can't be evaluated without consideration of factors in the other systems (Bronfenbrenner, 1977; Pianta \& Walsh, 1996).

\subsection{Teacher-child relationship}

Children develop attachment relationships with teachers predict late performance and achievements (Hamre,B.,\&Pianta,R.,2001;Pianta,1994;Ladd\&Burgess,2001;Birch\& Ladd, 1997). Earlier research has documented that high-quality teacher-child relationships are positively related to a wide range of academic and social-emotional outcomes (Ponitz, C. C., Rimm-Kaufman, S. E., Grimm, K. J., \& Curby, T. 
W.,2009;Luckner\&Pianta,2011;Pianta,1999), as well as to school adjustment (Pinata\&Steinberg,1992). Relationships between teachers and children are performed in a relatively complex system which is based on various factors,such as the context of the relationship,the child's home environment,the attachment patterns that child and teacher has developed (Sameroff,1995;Pianta,Hamre,\&Stuhlman,2003). Moreover,children may be able to develop different relationship types with teachers that are different from the relations they have formed with their parents.which may have unique and important implications for children with poor parent-child relationships (Howes,C.,Galinsky,E.,Kontos,S.,1998; van IJzendoorn et al.,1992). Children's environment is a critical factor when examining the teacher-child relationship which taken place through various interactions between teacher and child from kindergarten through 6 grade (Jerome,Hamre\&Pianta,2008). Pianta (2002) found that SES and race are possible factors which affecting the teacher-child relationship.For example,children from families with lower SES and maternal education are likely to performed less positive in the classroom and their study is more teacherdirected (Pianta et al.,2002). Gender has been reported to linked to teacher-child relationship.for example,boys are typically experience more conflict and less closeness compared with girls (Ladd et al.,1999; Saft\&Pianta,2001).

A broad range of environmental factors (i.e.,,parenting style,peer group) have been proved to affects children's relational behavior in school,in return influencing the quality of relationships that children form with teachers.For example,Children are well cared for in a high-quality home environment, and they also get a highquality care experience in school, which also results in high-quality teacher-student relationships (Jerome,Hamre\&Pianta,2008; National Institute of Child Health and Human Development Early Child Care Research Network,1997).

All the findings highlight the importance of teacher-child relationships on the children's development, and more attention needs to be devoted to the continued exploration of the relevance of these relationships.Based on the above theory and research,though various studies have illuminated predictors of teacher-child relationship quality in early years from the perspective of cognition, few have explored it from the relevance-theoretic perspective in mid-childhood,the present study therefore aims to gain a better understanding of the teacher-child relationship in children's media use with a focus on the teacher-child interaction,classroom adjustment and performance when transit from preschool to primary school.

\subsection{Children's media access and use in China}

China is a late comer on the research on children's media access and use.Starting in the 1980s, which can be divided into two phases.The first stage was from the 1980s to the end of the 1990s. With the rapid spread of television nationwide, the influence of television on children has become a hot spot of concern for the whole society. Issues of concern at this stage include:

1.The type of TV program, the time and frequency of viewing, and the difference between TV media and print media (Buo Wei, 1991, Dream Circle, 1997).

2.The motivation of children's media use, parental involvement, etc (Wu Wei, 1993, 1996).

3.Research on the impact of television on children, including the impact on children's health, morality, psychology, development, gender roles, and social attitudes and behaviors (Yang Zidi, 1985;Bu Wei, 1994, 1997, 1999; Yuan Chunqing, 1995).

In the second stage, from the beginning of the 1990s and after entering the 21 st century, the media ownership rate of urban families among children in China continued to rise. Owing to the support of the National Social Science Research Fund and cooperation with other subject projects, the research on children's media has made a comprehensive breakthrough in two aspects.

On one side, the scope of the study has expanded, which including children's media use in the amount of time, genre, frequency and individual differences.

The other side,regarding the content, it involves from television to computers, game consoles, etc (Chen Shuo, 2009; Lin Pin, 2009; Zhang Xinqiu, 2010).

The mass media is characterized by its generalized dissemination,openness, diversity and entertainment,It has played an active role in promoting emotional regulation of children in rural areas (Zhang,2008), diversifying children's personality and self-determination of values (Wang Yan, 2001; Han Ying, 2007) . However, Wang Gang also pointed out that the media mimetic environment is adultized, as well as the adultization of TV program content, misleading on the values of fame, fortune, money, and consumption, which has a negative impact on children's psychology (Wang,2008). Li Qi(2013)conducted a study on the children's media use and TV preferences in Shandong Province (aged from $0 \sim 12$ ) .In this study,the children displayed age differences on TV viewing time, motivation of TV viewing, and their personal preferences for content and type.

\subsection{The present study}

The present investigation (1) examined the correlation between children's media use and teacher-child relationship. (2) examined the impact of different media types on teacher-child relationships. (3) described the levels of association of children's media use with teacher relationships. (4) examined the potential trends in the impact of 
children's media use on teacher-child relationships.Based on the previous study on the quality of relationships between teacher and children and factors that contribute to these relationships, the hypotheses were made as follows:

1.There will be a correlation between children's media use and teacher-child relationship.Based on the research discussed above,we expect that when children enter to school,the amount of time children use media is related to the different types of relationships they have developed with their teachers.

2.Children's media use to different media genres have different effects on children's teacher-child relationship.We expect that children's use of different media is associated with various types of relationships between teachers.

3.Children's gender differences in media use have different effects on their teacher-student relationships. Based on previous findings that gender is linked to teacher-child relationship (Ladd et al.,1999;Saft\&Pianta,2001). We expect that gender differences in children's use of media are also reflected in differences in their impact on teacherstudent relationships.

\section{Methods}

A sample of 250 first grade children ( $\mathrm{N}=250,121$ girls, 129 boys) as well as their parents and teachers were participants in this study. Questionnaires were analyzed by SPSS 25.

\section{Measures}

1.General media use questionnaire

It contains 30 questions for children and family.Items of $\mathrm{TV}$,mobile phone,tablet and computer are included.

2.Teacher-Child Rating scale (T-CRS)

This scale is composed of 12 items and is answered using a Likert type 4-point scale $(1=$ behavior never occurs, $4=$ behavior almost always occurs). The T-CRS was designed to assess the school behaviors of young children, such as their social and emotional adjustment at school ((STRS;Pianta,R.C.,\& Steinberg,1992;Perkins \& Hightower,2002). The scale consists four domains of interactions and behaviors between teachers and children,it evaluates the teacher's feelings and beliefs about the children's actions toward him or her.Sample items are:'He/she has a satisfying relationship with me(teacher).He/she is willing to take the initiative to contact with me (teacher).' The reliability of this scale is $\alpha=.854$. The higher the score on this variable the more positive a teacher is about the student-teacher relationship.

1.Intimate teacher-child relationship

2.Avoiding teacher-child relationship

\section{Results}

Descriptive Statistics

Table 1

\section{The amount of time a first grade child spent on media everyday(2019.04-05)}

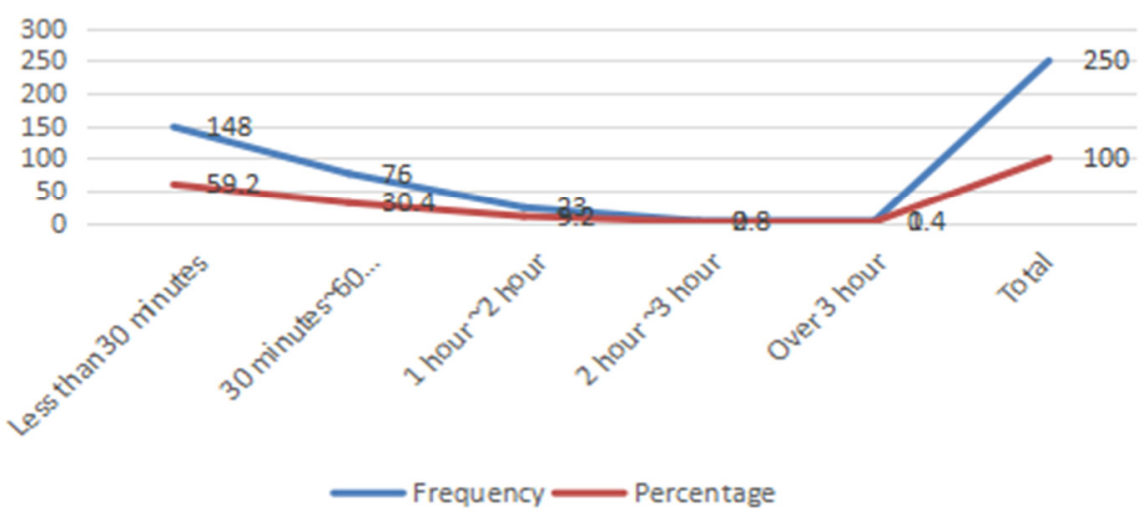

Table 1 shows that there are $59.2 \%$ of the children in first grade spent less than 30 minutes on media use per day, $30.4 \%$ of children spent $30 \sim 60$ minutes one day,and $9.2 \%$ of them spent $1 \sim 2$ hours on media everyday. 
Table $2 \mathrm{~T}$ - test for gender differences in amount of time of media use

\begin{tabular}{|c|c|c|c|c|c|c|}
\hline & \multicolumn{2}{|c|}{$\begin{array}{c}\text { Levene's Test for } \\
\text { Equality of Variances }\end{array}$} & \multicolumn{4}{|c|}{ t-test for Equality of Means } \\
\hline & \multirow[b]{2}{*}{$\mathrm{F}$} & \multirow[b]{2}{*}{ Sig. } & \multirow[b]{2}{*}{$\mathrm{t}$} & \multirow[b]{2}{*}{$\mathrm{df}$} & \multicolumn{2}{|c|}{$\begin{array}{c}95 \% \text { Confidence Interval of } \\
\text { the Difference }\end{array}$} \\
\hline & & & & & Lower & Upper \\
\hline $\begin{array}{ll}\text { How much time did you spend Equal variances } \\
\text { on media use every day? } & \text { assumed } \\
& \begin{array}{l}\text { Equal variances } \\
\text { not assumed }\end{array}\end{array}$ & 0.729 & 0. & $\begin{array}{r}1.806 \\
1.81\end{array}$ & 247.993 & $\begin{array}{l}-0.019 \\
-0.018\end{array}$ & $\begin{array}{l}0.437 \\
0.436\end{array}$ \\
\hline
\end{tabular}

test was conducted for gender difference in the amount of time of media use.t $=1.806(\mathrm{P}>0.05)$ shows no significance on the gender on the media use when the children at first grade.

Table 3 Correlations among variables

\begin{tabular}{llllllllll}
\hline 1 & 2 & 3 & 4 & 5 & 6 & 7 & 8 & 9 \\
\hline
\end{tabular}

\section{Teacher-child interactions}

\begin{tabular}{|c|c|c|c|c|c|c|c|c|c|}
\hline 1.Intimate teacher-child relationship & & $-.161 *$ & $.329 * *$ & $.434 * *$ & $-.418 * *$ & $* .297 * *$ & $-.234 * *$ & $.352 * *$ & $-.347 * *$ \\
\hline 2.Avoiding teacher-child relationship. & $.495 * *$ & & $-.433 * *$ & $-.367 * *$ & $.564 * *$ & $.224 * *$ & $.464 * *$ & $.263 * *$ & $.387 * *$ \\
\hline 3.classroom adjustment & $.517 * *$ & $-.207 * *$ & & $.581 * *$ & $-.663 * *$ & *.321** & $.261 * *$ & $.211 * *$ & $.351 * *$ \\
\hline 4.academic performance & $.643 * *$ & $-.300 * *$ & $.456^{* *}$ & & $-.529 * *$ & & $.351 * *$ & $-.414 * *$ & $.188 * *$ \\
\hline \multicolumn{10}{|l|}{ Children's media use } \\
\hline $\begin{array}{l}\text { 5. The amount of total time in media } \\
\text { use }\end{array}$ & $-.418 * *$ & $.564 * *$ & $-.663 * *$ & $-.529 * *$ & & $.119^{*}$ & $.244 * *$ & $.375^{* *}$ & $.199 * *$ \\
\hline 6.The content of TV program & $.297 * *$ & $.224 * *$ & $.321 * *$ & $.229 * *$ & $.139 *$ & & $-.141 *$ & -0.093 & -0.055 \\
\hline 7.the amount of TV watching time & $-.234 * *$ & $.278 * *$ & $.464 * *$ & $-.277 * *$ & $.159 *$ & $.414^{* *}$ & & 0.032 & 0.025 \\
\hline $\begin{array}{l}\text { 8.the amount of time in mobile phone. } \\
\text { use }\end{array}$ & $.352 * *$ & $.263 * *$ & $.211^{* *}$ & $-.414 * *$ & $.126^{*}$ & -0.093 & 0.032 & & $.123 *$ \\
\hline $\begin{array}{l}\text { 9.the amount of time spent in } \\
\text { internet(PC,tablelet) }\end{array}$ & $-.347^{*}$ & $.387 * *$ & $.351 * *$ & $.188 * *$ & $.199 * *$ & -0.055 & 0.025 & $.123 *$ & \\
\hline
\end{tabular}

The total time of children's media use showed a significant correlation with intimate teacher-child relationship $(\mathrm{r}=-.418, \mathrm{P}<0.01), \quad$ avoiding teacher-child $\quad$ relationship $(\mathrm{r}=.564, \mathrm{P}<0.01)$, classroom adjustment $(\mathrm{r}=-.663, \mathrm{P}<0.01)$ and academic performance $(\mathrm{r}=-.529, \mathrm{P}<0.01)$.

Among the scales,intimate teacher-child relationship includes for example,he/she is willing to talk to the teacher,He/she fully trusts his/her teacher,He/she worships the teacher.Avoidance teacher-child relationship includes he/she runs away from the teacher,he/she doesn't listen to the teacher.There is a significant correlation between the amount of time of children's media use and teacher-child relationship.

As table 3 shows, there is also a correlation between the classroom adjustment $(\mathrm{r}=-.663, \mathrm{P}<0.01)$, academic performance $(\mathrm{r}=-.529, \mathrm{P}<0.01)$ and media use (the amount of time $)$. 
Table 4 Correlations between children watching TV and teacher-child relationship

\begin{tabular}{|c|c|c|c|c|c|c|}
\hline TV watching & 2 & 56 & 7 & 8 & 9 & 10 \\
\hline \multicolumn{7}{|l|}{ 1.Types of TV program } \\
\hline \multicolumn{7}{|l|}{ 2.Frequency of watching TV } \\
\hline \multicolumn{7}{|l|}{ 3.Time period for watching TV(time slot) } \\
\hline \multicolumn{7}{|l|}{ Variables } \\
\hline 4.He/She is liked by teacher. & $-.136 * .-112 * .053$ & & & & & \\
\hline 5.He / she can concentrate in class. & $-.388 * *-.177 *-.114$ & & & & & \\
\hline 6.He/she admires the teacher. & .054 .030 .073 & & & & & \\
\hline 7.He/she has a sense of belonging to the class. & $-.201 * * .054 .015$ & & & & & \\
\hline 8.He/she trusts the teacher. & $-.175 * * .043 .071$ & & & & & \\
\hline $\begin{array}{l}\text { 9. He/she is willing to take the initiative to contact with the } \\
\text { teacher. }\end{array}$ & $-.238 * * .-055.034$ & & & & & \\
\hline $\begin{array}{l}\text { 10.He/she wants to be praised by the teacher. } \\
* \mathrm{P}<0.05, * * \mathrm{P}<0.01 \mathrm{~m}, * * * \mathrm{P}<0.000 \text {. }\end{array}$ & $.147 * .033-.029$ & & & & & \\
\hline
\end{tabular}

According to table 4,children spent the time on the types of TV program is related to teacher-child relationship and classroom performance. As shown in the table 4,there is a negative correlation between the TV program watching and the child is liked by teacher $(\mathrm{r}=-.136, \mathrm{P}<0.05)$, he/she has a sense of belonging to the class.( $\mathrm{r}=-.201, \mathrm{P}<0.01)$, he/she is willing to take the initiative to contact with the teacher $(\mathrm{r}=-.238, \mathrm{P}<0.01), \mathrm{He} / \mathrm{she}$ trusts the teacher $(\mathrm{r}=-.175, \mathrm{P}<0.01)$, he $/$ she can concentrate in class $(\mathrm{r}=-.388, \mathrm{P}<0.01)$. Also,the frequency with which children watch TV is related to whether they can concentrate in the classroom $(r=-.177, P<0.05)$ and whether they are liked by the teacher $(\mathrm{r}=-.112, \mathrm{P}<0.05)$. Regarding the time period for watching $\mathrm{TV}$, there is no significant between teacher-child relationship,classroom adjustment and the time slot that when children watch TV.

From the above data results, we can see that the frequency and content of children watching TV is related to teacher-child relationships and classroom adjustment, but not to time slot.

Table 5 Correlations between children's mobile phone use and teacher-child relationships and classroom adjustment

\begin{tabular}{|l|l|l|l|}
\hline & $\begin{array}{l}1 . \text { Make calls or text } \\
\text { message }\end{array}$ & $\begin{array}{l}2 . \text { Play } \\
\text { games }\end{array}$ & $\begin{array}{l}3 . \text { learning } \\
\text { tools }\end{array}$ \\
\hline He/she has a sense of belonging to the class. & -.012 & $-.126^{*}$ & $.352^{* *}$ \\
\hline $\begin{array}{l}\text { He/she is willing to take the initiative to contact with the } \\
\text { teacher. }\end{array}$ & .060 & $-.158^{*}$ & $-.165^{* *}$ \\
\hline He/she admires the teacher. & -.045 & $-.127^{*}$ & $-.559^{* *}$ \\
\hline $\mathrm{He} /$ she can concentrate in class. & -.036 &.$-481^{* *}$ & $-.172^{* *}$ \\
\hline $\mathrm{He} /$ She is liked by teacher. & .009 &.$-164^{* *}$ & $.324^{* *}$ \\
\hline$* \mathrm{P}<0.05, * * \mathrm{P}<0.01 \mathrm{~m}, * * * \mathrm{P}<0.000$. & & \\
\hline
\end{tabular}

Table 5 indicates that children use mobile phones for different purposes, they have different association with teacher-child relationships and classroom adjustment.Calling or texting with a mobile phone was not significantly related to the teacher-child relationship at school and classroom performance, While Playing games on mobile phones has a significant negative correlation with them. The most relevant is the child's inability to focus on the classroom $(\mathrm{r}=.-481, \mathrm{P}<0.01)$ In using a mobile phone as a learning tool, it is positively related to the child's sense of belonging in the classroom $(\mathrm{r}=.352, \mathrm{P}<0.01)$ and he/She is liked by teacher $(\mathrm{r}=.324, \mathrm{P}<0.01)$, while it is significantly negatively related to children worship/admire teachers $(\mathrm{r}=.-559, \mathrm{P}<0.01)$, and negatively related to he/she is willing to take the initiative to contact with the teacher $(\mathrm{r}=.-165, \mathrm{P}<0.01)$. meanwhile, it is negatively related to he /she can concentrate in class $(\mathrm{r}=.-172, \mathrm{P}<0.01)$.

Table 6 Regression analysis of children's media use and worship teachers

\begin{tabular}{|ll|r|r|r|r|r|}
\hline Model & \multicolumn{1}{|c|}{ SS } & df & MS & F & Sig. \\
\hline 1 & Regression & 3.741 & 1 & 3.741 & 4.436 & \\
& Residual & 209.159 & 248 & .843 & & \\
& Total & 212.900 & 249 & & & \\
\end{tabular}

a. Dependent Variable: He/she admires the teacher.

b. Predictors: (Constant), How much time did you spend on media use every day? 
Table 7 Coefficients

\begin{tabular}{|c|c|c|c|c|c|c|c|}
\hline \multicolumn{8}{|c|}{ Coefficients ${ }^{\mathrm{a}}$} \\
\hline \multirow[b]{2}{*}{ Model } & \multicolumn{2}{|c|}{$\begin{array}{l}\text { Unstandardized } \\
\text { Coefficients }\end{array}$} & \multirow{2}{*}{$\begin{array}{c}\text { Standardized } \\
\text { Coefficients } \\
\text { Beta } \\
\end{array}$} & \multirow[b]{2}{*}{ t } & \multirow[b]{2}{*}{ Sig. } & \multicolumn{2}{|c|}{$\begin{array}{l}95.0 \% \text { Confidence Interval } \\
\text { for B } \\
\end{array}$} \\
\hline & B & Std. Error & & & & $\begin{array}{l}\text { Lower } \\
\text { Bound }\end{array}$ & $\begin{array}{l}\text { Upper } \\
\text { Bound }\end{array}$ \\
\hline (Constant) & 4.536 & .161 & & 28.221 & .000 & 4.219 & 4.852 \\
\hline $\begin{array}{l}\text { How much time did } \\
\text { you spend on media } \\
\text { use every day? }\end{array}$ & -.134 & .063 & -.133 & -2.106 & .036 & -.258 & -.009 \\
\hline
\end{tabular}

a. Dependent Variable: He/she admires the teacher.

Regression analysis was performed for children's media use and worship teachers,as it shows above, $\mathrm{F}(1,248)=4.436, \mathrm{p}=0.036<0.05$, Beta $=-.133(\mathrm{t}=-2.106, \mathrm{p}=0.036)$, children's media use time can predict the worship of teachers,which indicates that the longer a child uses the media, the less likely he / she will admire/worship the teacher.

Table 8 one-way ANOVA test

ANOVA

tcrelationship

\begin{tabular}{|l|r|r|r|r|}
\hline \multicolumn{1}{|c|}{ SS } & df & Mean Square & F \\
\hline Between Groups & 78.570 & 1 & 78.570 & 1.523 \\
Within Groups & 12791.030 & 248 & 51.577 & .218 \\
Total & 12869.600 & 249 & & \\
\end{tabular}

A one-way ANOVA was conducted for children's gender differences in media use(the amount of time) have different effects on their teacher-student relationships. According to table $8, \mathrm{~F}=1.523, \mathrm{p}=.218>0.05$, the test results shows that there is no significant gender difference in the impact of children's media use time on teacher-child relationships.

\section{Discussion}

The primary purpose of this study was to examine associations between children's media use and teacher-child relationships from preschool through first grade and classroom adjustment at first grade.The literature indicates that high-quality teacher-child relationships are associated with long-term development and achievement; however,the effects of other environmental factors(like media environment) on the association between relationship quality and achievement have not been evaluated. To understand more fully the impact of quality of teacher-child relationships on children's school adjustment and achievement, relationships must be studied in the ecological context (Pianta\& Walsh, 1996).

Results from this investigation indicates significant association between children's media use and teacherchild relationships.Firstly,the total amount of time used by children's media was significantly correlated with intimate or avoiding teacher-child relationships.Specifically, the frequency and content of children watching TV is related to teacher-child relationships and classroom adjustment, but not to time slot,these findings suggest that interventions focused on improving children's relationships with teachers should pay attention to the contents of TV programs and the reasonable frequency for children to watch TV.

The findings regarding the correlation between children's media use and worship of the teacher indicates that teachers' use of mobile phones, computers, and tablets to assign assignment is also a potential risk factor for increasing children's use of media,As a result, children's worship of teachers is reduced, which can hinder the relationship between teachers and children,which can also lead to poor classroom adjustment and performance (Eisenhower, Baker, \& Blacher, 2007;Pianta, \& Stuhlman, 2004; Pianta, 1999).

The quality of the teacher-child relationship has been found to be related to teachers' expectations and children's performance and background (Gingles,\&Price,1993;Pianta.R,Stuhlman.M, 2004b,). Previous literature has demonstrated that students' behaviors and learning motivation in the classroom have an impact on teachers' expectations for their future academic performance (Cooper, H., Findley, M.,\&Good, T., 1982; Hecht\&Greenfield, 2002), in return teachers' expectations can affect the subsequent teacher's behavior and student performance (Hamre, B.K., Pianta, R.C., Burchinal, M. el,2012; Ready\&Wright,2011). The results of this study indicated that the longer a child uses the media, the less likely he/she will admire/worship the teacher,which in line with the previous study about the ecological context (Bronfenbrenner,1977). A possible explanation for this finding is that the teacher expects different academic performance according to the classroom behavior of the children, and hopes to achieve it by assigning homework at different levels. In this process, children's use of media has a new impact on the teacher-child relationship. 


\section{Educational Implications}

The current findings have implications for teacher education programs. Positive teacher-child relationships predict children's social and academic development. (Baker,2006;Pianta,Steinberg,\& Rollins, 1995; Valiente, LemeryChalfant,Swanson, \& Reiser, 2008;Hamre\& Pianta,2001). From this study, however, it gives a insight for elementary school teachers how to foster high-quality relationships with children.This research demonstrates that teachers use the media ( e.g.,use tablet or phone )to assign assignments to improve students' academic performance while at a risk in turn become a stumbling block to high-quality teacher-child relationships.

The results of the current study open important pathways for future research into the question: what is the association between children's motivation for media use and teacher-child relationships. For example,do children use the media because of avoiding the teacher, or because of low self-identity in the class, or because the use of various media lead to alienation from the teacher? Are there certain factors to be influenced by media use when it comes to formulating high quality teacher-child relationship? And if that is the case, this research could be extended with an investigation of how children's media use with different contents and motivation be a modulator between child temperament and teacher-child interaction in classroom.

\section{References}

1. Acquah, E. Palonen, T. Laine, K. \& Lehtinen, E. (2014). Social status and social behaviour among first graders. Scandinavian Journal of Educational Research, 58 (1), 73-92.

2. Ariana Pavelka,The Impact of Teacher-Child Relationships on Social Adjustment and Behaviour in Schools,Journal of Initial Teacher Inquiry (2016). Volume 2,P2-5

3. Baker, Jean. (2006). Contributions of teacher-child relationship to positive school adjustment during elementary school. Journal of School Psychology. 44. 211-229. 10.1016/j.jsp.2006.02.002.

4. Birch SH, Ladd GW. The teacher-child relationship and children's early school adjustment. Journal of School Psychology. 1997;35:61-79.

5. Bronfenbrenner, U. (1977). Experimental toward an Ecology of Human Development. American Psychologist, 32, 513-531. http://dx.doi.org/10.1037/0003-066X.32.7.513

6. Bronfenbrenner, Urie \& Morris, Pamela. (2007). The Bioecological Model of Human Development. 10.1002/9780470147658.chpsy0114.

7. Bronfenbrenner, Urie. "Toward an experimental ecology of human development." (1977).

8. Buss, K., Gingles, J., \& Price, J. (1993). Parent-teacher temperament ratings and student success in reading.Reading Psychology,14(4), 311-323.

9. Camilli, G., Vargas, S., Ryan, S., \& Barnett, W. S. (2010). Meta-analysis of the effects of early education interventions on cognitive and social development. Teachers College Record, 112(3), 579-620.

10. Claessens, Engel, \& Curran,(2013).Academic Content, Student Learning, and the Persistence of Preschool Effects,American Educational Research Journal 51(2):403-434.

11. Cooper, H., Findley, M., \& Good, T. (1982). Relations between student achievement and various indexes of teacher expectations. Journal of Educational Psychology,74,570-577. doi:10.1037/0022-0663.74.4.577.

12. DuPaul, G.J., Morgan, P.L., Farkas, G. et al. Academic and Social Functioning Associated with AttentionDeficit/Hyperactivity Disorder: Latent Class Analyses of Trajectories from Kindergarten to Fifth Grade.J Abnorm Child Psychol 44,1425-1438 (2016) https://doi.org/10.1007/s10802-016-0126-z

13. Eisenhower AS, Baker BL, Blacher J. Early student-teacher relationships of children with and without intellectual disability: Contributions of behavioral, social, and self-regulatory competence. Journal of School Psychology. 2007;45:363-383.

14. Entwisle, D. R., \& Alexander, K. L. (1998). Facilitating the transition to first grade: The nature of transition and research of factors affecting it. Elementary School Journal, 98(4), 381-397. EJ561643.

15. Guerin, Diana \& Gottfried, Allen \& Oliver, Pamella \& Thomas, Craig. (1994). Temperament and School Functioning during Early Adolescence. Journal of Early Adolescence - J EARLY ADOLESCENCE. 14. 200225. 10.1177/027243169401400206.

16. Gutman, L. M., Sameroff, A. J., \& Cole, R. (2003). Academic growth curve trajectories from 1st grade to 12th grade: Effects of multiple social risk factors and preschool child factors. Developmental Psychology, 39(4), 777-790. https://doi.org/10.1037/0012-1649.39.4.777

17. Hamre, B. K., \& Pianta, R. C. (2001). Early teacher-child relationships and the trajectory of children's school outcomes through eighth grade. Child Development, 72, 625-638.

18. Hamre, B., \& Pianta, R. (2001). Early Teacher-Child Relationships and the Trajectory of Children's School Outcomes Through Eighth Grade. Child Development, 72(2), 625-638. Retrieved January 18, 2020, from www.jstor.org/stable/1132418

19. Hamre, B.K., Pianta, R.C., Burchinal, M., Field, S, Crouch, J.L., Downer, J. T., Howes, C., LaParo, K., Little, C.S. (2012). A course on effective teacher-child interactions: Effects on teacher beliefs, knowledge, and observed practice. American Educational Research Journal, 49:1, 88-123. 
20. Hecht, S. A., \& Greenfield, D. B. (2002). Explaining the predictive accuracy of teacher judgments of their students' reading achievement: The role of gender, classroom behavior, and emergent literacy skills in a longitudinal sample of children exposed to poverty. Reading and Writing: An Interdisciplinary Journal, 15, 789-809. doi:10.1023/A:1020985701556.

21. Howes, C., Galinsky, E., Kontos, S. (1998). Child care caregiver sensitivity and attachment. Social Development, 4, 44-61.

22. Jerome, E. M., Hamre, B. K., \& Pianta, R. C. (2008). Teacher-child relationships from Kindergarten to sixth grade: Early childhood predictors of teacher-perceived conflict and closeness. Social Development, 18, $915-$ 945.

23. Krakouer, Jacynta; Mitchell, Pru; Trevitt, Jenny; and Kochanoff, Anita, "Early years transitions: supporting children and families at risk of experiencing vulnerability: rapid literature review" (2017). https://research.acer.edu.au/early_childhood_misc/9

24. Kupersmidt, J., \& Coie, J. (1990). Preadolescent Peer Status, Aggression, and School Adjustment as Predictors of Externalizing Problems in Adolescence. Child Development, 61(5), 1350-1362. doi:10.2307/1130747

25. Ladd GW, Burgess KB,Do relational risks and protective factors moderate the linkages between childhood aggression and early psychological and school adjustment?Child Dev. 2001 Sep-Oct; 72(5):1579-601.

26. Ladd, G. W., \& Burgess, K. B. (1999). Charting the relationship trajectories of aggressive, withdrawn, and aggressive/withdrawn children during early grade school. Child Development, 70, 910-929.

27. Luckner, Amy \& Pianta, Robert. (2011). Teacher-student interactions in fifth grade classrooms: Relations with children's peer behavior. Journal of Applied Developmental Psychology - J APPLIED DEV PSYCHOLOGY. 32. 257-266. 10.1016/j.appdev.2011.02.010.

28. NICHD early child care research network. (1997). child care in the first year of life. Merrill Palmer Quarterly, 43, 340-360.

29. Perkins, P.E. , \& Hightower, A.D. (2002). T-CRS 2.1: Teacher-child rating scale: Examiner's manual. Rochester, NY: Children's Institute.

30. Pianta R, Stuhlman M. Teacher-child relationships and children's success in the first years of school. School Psychology Review. 2004b;33:444-458.

31. Pianta, R. C. \& Steinberg, M. (1992). Teacher-child relationships and the process of adjusting to school.New Directions for Child Development,57, 61-80. http://dx.doi.org/10.1002/cd.23219925706

32. Pianta, R. C. (1999). Enhancing relationships between children and teachers. American Psychological Association. https://doi.org/10.1037/10314-000

33. Pianta, R. C. (1999). Enhancing relationships between children and teachers. Washington,DC: American Psychological Association.

34. Pianta, R. C. (2001). Student-Teacher Relationship Scale: Professional manual. Odessa, FL:Psychological Assessment Resources, Inc.

35. Pianta, R. C., \& Steinberg, M. (1992). Teacher-child relationships and the process of adjusting to school. In R. C. Pianta (Ed.), Beyond the parent: The role of other adults in children's lives. New directions for child development, Vol. 57 (pp. 81-107). San Francisco, CA: Jossey-Bass.

36. Pianta, R. C., \& Stuhlman, M. W. (2004). Teacher-child relationships and children's success in the first years of school. School Psychology Review, 33(3), 444-458.

37. Pianta, R. C., \& Stuhlman, M. W. (2004). Teacher-Child Relationships and Children's Success in the First Years of School. School Psychology Review, 33(3), 444-458.

38. Pianta, R. C., \& Walsh, D. J. (1996). High-risk children in schools: Constructing sustaining relationships. New York: Routledge.

39. Pianta, R. C., Cox, M. J., Taylor, L., \& Early, D. (1999). Kindergarten teachers' practices related to transition into schools: Results of a national survey, Elementary School Journal, 100, 71-86.

40. Pianta, R. C., Hamre, B. K., \& Stuhlman, M. (2003). Relationships between teachers and children. In W. Reynolds, \& G. Miller (Eds.), Comprehensive handbook of psychology.

41. Pianta, R. C., La Paro, K. M., \& Payne, C., Cox, M., \& Bradley, R. (2002). The relation of kindergarten classroom environment to teacher, family, and school characteristics and child outcomes. Elementary School Journal, 102(3), 225-238.

42. Pianta, R. C., Steinberg, M. S., \& Rollins, K. B. (1995). The first two years of school: Teacher-child relationships and deflections in children's classroom adjustment. Development and Psychopathology, 7(2), 295-312. https://doi.org/10.1017/S0954579400006519

43. Pianta, R. C., Steinberg, M., \& Rollins, K. (1995). The first two years of school: Teacher-child relationships and deflections in children's classroom adjustment. Development and Psychopathology, 7(1), 295-312.

44. Ponitz, C. C., Rimm-Kaufman, S. E., Grimm, K. J., \& Curby, T. W. (2009). How Kindergarten Classroom Quality Contributes to Reading Achievement: The Critical Role of Behavioral Engagement. School Psychology Review, 38, 102-120. 
45. Ready, Douglas \& Wright, David. (2011). Accuracy and Inaccuracy in Teachers' Perceptions of Young Children's Cognitive Abilities: The Role of Child Background and Classroom Context. American Educational Research Journal - AMER EDUC RES J. 48. 335-360. 10.3102/0002831210374874.

46. Rudasill, K. M., \& Rimm-Kaufman, S. E. (2009). Teacher-child relationship quality: The roles of child temperament and teacher-child interactions. Early Childhood Research Quarterly, 24(2), 107-120. https://doi.org/10.1016/j.ecresq.2008.12.003

47. Saft, Elizabeth \& Pianta, Robert. (2001). Teachers' Perceptions of Their Relationships with Students: Effects of Child Age, Gender, and Ethnicity of Teachers and Children. School Psychology Quarterly - SCHOOL PSYCHOL QUART. 16. 125-141. 10.1521/scpq.16.2.125.18698.

48. Sameroff, A. J. (1995). General systems theory and developmental psychopathology. In D. Cicchetti \& D. J. Cohen (Eds.), Developmental psychopathology, Vol. 1, theory and methods (pp. 659-695). New York, NY: Wiley \& Sons.

49. Valiente, C., Lemery, K., Swanson, J., \& Reiser, M. (2008). Prediction of Children's Academic Competence From Their Effortful Control, Relationships, and Classroom Participation. Journal of Educational Psychology, 100(1), 67-77. https://doi.org/10.1037/0022-0663.100.1.67

50. van IJzendoorn, M. H., Goldberg, S., Kroonenberg, P. M. \& Frenkel, O. J. (1992). The relative effects of maternal and child problems on the quality of attachment: A meta-analysis of attachment in clinical samples.( Child Development, 63, 840-858.)

51. Verschueren, K., \& Koomen, H. M.Y. (2012). Teacher-child relationships from an attachment perspective.Attachment\&HumanDevelopment,14(3),205211.https://doi.org/10.1080/14616734.2012.672260 